\title{
PENGUKURAN KINERJA PRODUKSI HOT STRIP MILL DENGAN METODE OVERALL EQUIPMENT EFFECTIVENESS (OEE) (Studi Kasus pada Industri Baja di Cilegon, Banten)
}

\author{
Nashrullah Setiawan ${ }^{1}$ dan Mauvina Annisa ${ }^{2}$ \\ Jurusan Teknik Industri, Fakultas Teknologi Industri, Universitas Islam Indonesia, ${ }^{1,2)}$ \\ Jl. Kaliurang Km. 14,5 Sleman, Yogyakarta 55584 \\ E-Mail:wawan.st01@gmail.com ${ }^{l}$
}

\begin{abstract}
The Overall Equipment Effectiveness (OEE) is the performance measurement tool for stabilizing process in industrial manufacturing. It becomes a comprehensive analysis method from a strategic to operational point of view to optimize measurement result. This study aims to examine gap case studies of performance measurement results of Hot Strip Mill production using OEE method in one of the largest steel industry in Cilegon Banten. The research methodology includes determination of measurement variables, secondary data collection (i.e. production time data, total production and total product defect), interviews and field observations, and analysis of factors causing the gap between target and actual performance. Based on data processing, the result of performance measurement is: 61\% (availability), 63\% (performance), 95\% (quality) and 42\% (OEE). Based on pareto analysis and fishbone diagram, it is known that dominant cause factor is delay time and high demand variation.
\end{abstract}

Keywords : Overall Equipment Effectiveness, Machine Effectiveness, Performance.

\section{PENDAHULUAN}

Pengukuran kinerja produksi memiliki relevansi yang sangat kuat dalam mewujudkan tingkat efektivitas dan efisiensi kerja perusahaan secara keseluruhan. Hal tersebut dapat dilihat dari upaya proses produksi yang selalu berorientasi kepada pemenuhan kebutuhan konsumen, baik secara kuantitas maupun kualitas. Di samping itu, sistem pengukuran yang dibangun juga mengacu kepada capaian stabilitas dan kontinuitas proses operasi sehingga akan berdampak pada perbaikan dan peningkatan kinerja.

Penelitian ini, secara umum bertujuan untuk melakukan kajian terhadap pengukuran kinerja proses produksi di perusahaan baja terpadu di Indonesia, dimana semua kegiatan proses produksi dari hulu sampai ke hilir ada pada satu tempat di Cilegon, Banten. Perusahaan ini merupakan perusahaan manufaktur skala besar yang telah melakukan ekspor produk di Asia Tenggara.
Saat ini, industri baja tersebut memiliki standar tersendiri dalam menilai tingkat produktivas mesin yang disebut dengan Ton Per Hour atau TPH. Adapun nilai standar atau target yang ditetapkan untuk mengukur tingkat keberhasilan capaian proses produksi yang dilakukan oleh perusahaan baja tersebut adalah sebanyak 300 ton/hour.

Berikut ini adalah gambaran capaian hasil kinerja proses produksi pada Hot Strip Mill berdasarkan indikator TPH dalam satu bulan yang diobservasi.

Berdasarkan gambar 1 diketahui bahwa selama periode bulan Februari 2017 hasil produksi perusahaan masih dibawah target dengan rata-rata sebesar 190 ton/hour. Dari grafik tersebut terlihat bahwa ada ketidaktercapaian hasil berdasarkan ukuran TPH pada proses Hot Strip Mill. Namun demikian, indikator pengukuran tersebut belum dapat menginformasikan tentang hasil 
Tabel 1. World Class Standard OEE.

World Class Standard

\begin{tabular}{cc}
\hline Availability & $90 \%$ \\
Performance & $95 \%$ \\
Quality & $99,9 \%$ \\
OEE & $85 \%$ \\
\hline
\end{tabular}

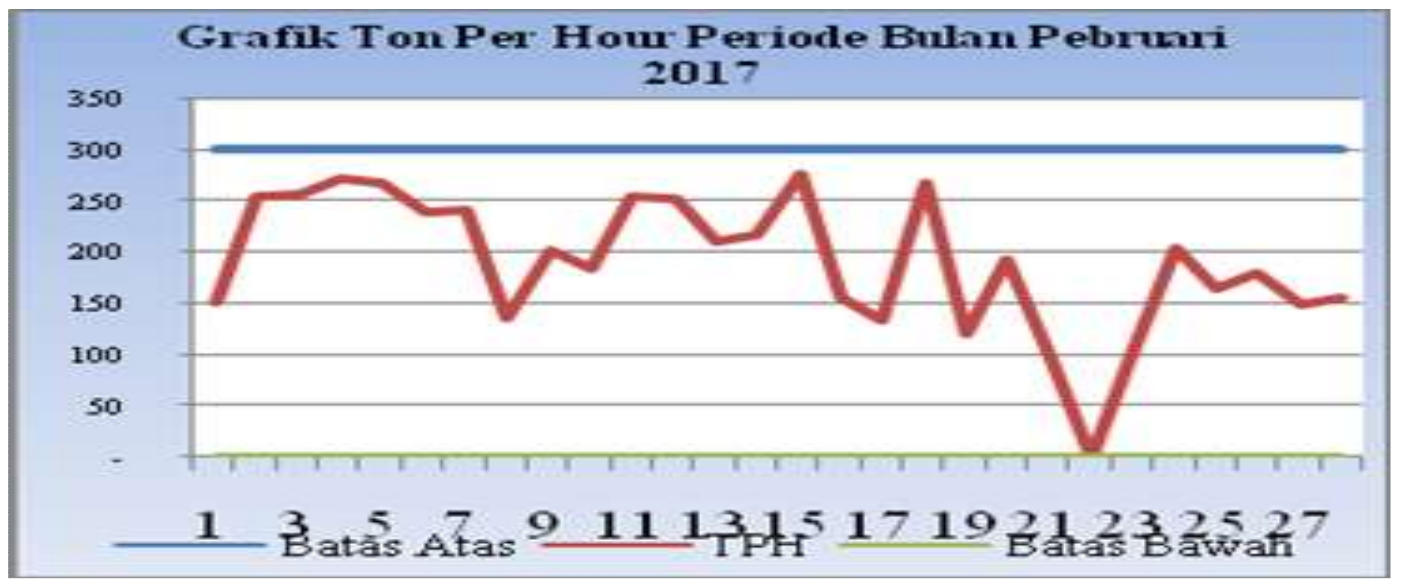

Gambar 1. Grafik Ton Per Hour.

secara lebih komprehensif sehingga dapat dilakukan identifkasi lanjutan terhadap faktor - faktor penyebab ketidaktercapaian hasil.

Berdasarkan permasalahan tersebut, maka penelitian ini bertujuan untuk mengkaji penerapan Overall Equipment Effectiveness (OEE) pada perusahaan tersebut, sehingga dapat dilihat factor faktor yang berpengaruh secara lebih spesifik pada proses produksi Hot Strip Mill.

Beberapa contoh keuntungan penerapan daripada metode tersebut adalah pertama, OEE merupakan ukuran kinerja yang penting untuk menilai efektivitas peralatan dalam melakukan produksi. Pengukuran ini berdasarkan kepada keseluruhan komponen yang terlibat dalam proses produksi sehingga hasil yang diperoleh sangat penting bagi jenis industri manapun (Meet Lalkiya et al., 2015).
Kedua, OEE memiliki kemampuan dalam menjaga nilai kinerja produksi dan dapat dijadikan sebagai alat perbaikan terusmenerus (Mit Patel et al., 2016).

Ketiga, Overall Equipment Effectiveness (OEE) dapat dijadikan sebagai salah satu Key Performance Indicator dalam mengukur kinerja perusahaan sehingga penilaian yang dilakukan dapat mengubah sistem manajemen yang ada dalam perusahaan tersebut dan meningkatkan kinerja perusahaan menjadi lebih baik (Fakhruddin Esa dan Yusri Yusof, 2016).

Keempat, dalam penerapannya, OEE menjadi salah satu metode yang dapat membantu perusahaan Water Bottling dalam mengetahui titik kelemahan dan untuk mengidentifikasi kerugian manufaktur dari perusahaannya tersebut (Vittaleshwar A et.al, 2016). 
Kelima, OEE merupakan nilai yang dinyatakan sebagai rasio antara output aktual dibagi output maksimum dari peralatan pada kondisi kinerja yang terbaik, sehingga dapat dijadikan sebagai alat ukur performa dari suatu sistem maintenance. Dengan menggunakan metode ini maka dapat diketahui ketersediaan mesin / peralatan (availability), efisiensi produksi (performance), dan kualitas output mesin / peralatan (Seiichi Nakajima, 1988).

Delapan Pilar Strategi yang merupakan salah satu komponen dalam Total Productive Maintenance (TPM) digunakan sebagai bahan evaluasi dan pertimbangan terhadap nilai OEE yang didapatkan. Strategi ini dilakukan menurunkan tingkat kegagalan dengan konsep Zero Production Defects, Zero Breakdowns, dan meminimalkan kerugian produksi juga mengoptimalkan keefektifan peralatan. Penerapan Delapan Pilar Strategi TPM merupakan upaya dalam melakukan peningkatan kinerja perusahaan, sehingga penerapan tersebut diharapkan dapat meningkatkan nilai OEE yang rendah menjadi sesuai World Class Standar. (Soraphon Kigsirisin et al., 2016).

Melalui Total Productive Maintenance dengan melakukan pengukuran mesin menggunakan metode Overall Equipment Effectiveness (OEE) dapat diaplikasikan delapan pilar yang akan menjaga fungsi peralatan maupun material pendukung produksi sehingga dapat memperhatikan peningkatan produktivitas dari para operator yang akan memegang kendali mesin secara langsung dalam proses produksi. (Afif Fahmi et al, 2013).

Dengan visi yang dimiliki yaitu menjadi perusahaan yang terkemuka di dunia, maka perolehan hasil perhitungan pengukuran kinerja produksi dapat dibandingkan dengan standar nilai kelas dunia. Sehingga, berdasarkan hasil pengukuran dapat diketahui nilai yang dihasilkan sudah mencapai visi dari perusahaan tersebut atau belum.
Japan Institute of Plant Maintenance (JIPM) telah menetapkan standar benchmark yang telah dipraktekan secara luas di seluruh dunia. Benchmark dari penilaian OEE terdapat pada tabel 1. Penggunaan metode OEE dinilai relevan dalam mengukur kinerja produksi yang mengacu pada efektivitas mesin dan mengkombinasi hasil pengukuran dengan pareto diagram untuk mengidentifikasi mengenai faktor dominan sehingga dapat dianalisis menggunaan fishbone diagram untuk mencari penyebab tidak tercapainya nilai OEE.

\section{METODE PENELITIAN}

Untuk melakukan pengukuran kinerja produksi pada industri baja tersebut digunakan metode Overall Equipment Effectiveness (OEE) melalui efektivitas mesin / peralatan yang digunakan oleh perusahaan.

Data yang digunakan merupakan data sekunder yang berasal dari arsip perusahaan dimana data merupakan hasil laporan harian selama menjalankan proses produksi. Datadata tersebut adalah sebagai berikut :

\section{Data Waktu Produksi}

Didalam data ini mencakup keseluruhan indikator dalam menghitung waktu operasi mesin antara lain adalah waktu, delay, waktu idle, waktu produksi, waktu set-up serta waktu reparasi mesin dan juga total waktu perencanaan produksi dan juga hasil produksi (output) harian.

2. Data Jumlah Defect

Data ini berisi tentang jumlah produk cacat pada produksi harian. Sehingga, dalam perhitungannya didapatkan jumlah produk yang baik untuk didistribusikan.

Metode OEE sendiri memiliki tiga komponen utama pada mesin produksi yaitu Availability (Waktu Kesediaan Mesin), Performance (Jumlah unit yang diproduksi) dan Quality (Mutu yang dihasilkan). Hasil perhitungan OEE adalah dalam bentuk Prosentase (\%). 
Tabel 2. Hasil Perhitungan OEE

\begin{tabular}{|c|c|c|c|c|}
\hline Tanggal & Availability & Performance & Quality & OEE \\
\hline 1 & $44 \%$ & $50 \%$ & $98 \%$ & $22 \%$ \\
\hline 2 & $74 \%$ & $84 \%$ & $99 \%$ & $62 \%$ \\
\hline 3 & $75 \%$ & $85 \%$ & $100 \%$ & $64 \%$ \\
\hline 4 & $77 \%$ & $90 \%$ & $99 \%$ & $69 \%$ \\
\hline 5 & $70 \%$ & $89 \%$ & $99 \%$ & $62 \%$ \\
\hline 6 & $76 \%$ & $79 \%$ & $99 \%$ & $60 \%$ \\
\hline 7 & $83 \%$ & $80 \%$ & $98 \%$ & $66 \%$ \\
\hline 8 & $37 \%$ & $45 \%$ & $99 \%$ & $16 \%$ \\
\hline 9 & $63 \%$ & $67 \%$ & $99 \%$ & $42 \%$ \\
\hline 10 & $56 \%$ & $61 \%$ & $98 \%$ & $33 \%$ \\
\hline 11 & $72 \%$ & $84 \%$ & $100 \%$ & $60 \%$ \\
\hline 12 & $82 \%$ & $84 \%$ & $100 \%$ & $68 \%$ \\
\hline 13 & $81 \%$ & $70 \%$ & $100 \%$ & $56 \%$ \\
\hline 14 & $74 \%$ & $72 \%$ & $100 \%$ & $53 \%$ \\
\hline 15 & $78 \%$ & $92 \%$ & $96 \%$ & $69 \%$ \\
\hline 16 & $59 \%$ & $52 \%$ & $100 \%$ & $31 \%$ \\
\hline 17 & $42 \%$ & $45 \%$ & $91 \%$ & $17 \%$ \\
\hline 18 & $74 \%$ & $89 \%$ & $100 \%$ & $66 \%$ \\
\hline 19 & $35 \%$ & $40 \%$ & $98 \%$ & $14 \%$ \\
\hline 20 & $57 \%$ & $64 \%$ & $98 \%$ & $36 \%$ \\
\hline 21 & $33 \%$ & $32 \%$ & $100 \%$ & $11 \%$ \\
\hline 22 & $0 \%$ & $0 \%$ & $0 \%$ & $0 \%$ \\
\hline 23 & $46 \%$ & $33 \%$ & $95 \%$ & $15 \%$ \\
\hline 24 & $66 \%$ & $68 \%$ & $98 \%$ & $44 \%$ \\
\hline 25 & $75 \%$ & $55 \%$ & $100 \%$ & $41 \%$ \\
\hline 26 & $56 \%$ & $60 \%$ & $99 \%$ & $33 \%$ \\
\hline 27 & $49 \%$ & $50 \%$ & $99 \%$ & $24 \%$ \\
\hline 28 & $63 \%$ & $52 \%$ & $99 \%$ & $32 \%$ \\
\hline Rata - rata & $61 \%$ & $63 \%$ & $95 \%$ & $42 \%$ \\
\hline
\end{tabular}


Tabel 3. Perbandingan Standar Dunia \& Nilai Aktual Perusahaan

\begin{tabular}{ccc}
\hline & World Class Standard & Nilai Aktual Industri Baja \\
\hline Availability & $90 \%$ & $61 \%$ \\
Performance & $95 \%$ & $63 \%$ \\
Quality & $99,9 \%$ & $95 \%$ \\
OEE & $85 \%$ & $42 \%$
\end{tabular}

Rumus dari perhitungan nilai OEE (Overall Equipment Effectiveness) adalah sebagai berikut :

Awallability $=\frac{\text { Operation Time }}{\text { Planned Production Time }} \times 100 \%$

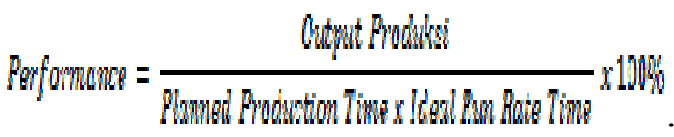

Quality $=\frac{\text { Good Product }}{\text { Hasil Product }} \times 100 \%$

OEE = Availability $x$ Performance $x$ Quality

\section{HASIL DAN PEMBAHASAN}

Penelitian dilakukan pada kinerja Hot Strip Mill dengan menggunakan data waktu produksi periode Februari 2017, data defect produk dan juga data hasil produksi.

Dari hasil perhitungan ketiga faktor tersebut didapatkan nilai OEE pada produksi Hot Strip Mill periode Februari 2017 pada tabel 2.

Berdasarkan hasil perhitungan yang ada pada tabel 3 bahwa diketahui menurut ratarata tersebut nilai OEE yang ada pada divisi Hot Strip Mill belum sesuai dengan World Class Standard.
Untuk mengetahui faktor apa saja yang menyebabkan rendahnya nilai OEE yang didapatkan oleh perusahaan, maka dibuatlah diagram Pareto dan diagram Sebab - Akibat untuk mengetahui secara spesifik faktor tersebut. Berdasarkan dengan gambar 2 diketahui bahwa waktu delay pada data waktu produksi menunjukan waktu tersebut merupakan salah satu faktor dalam rendahnya nilai OEE yang didapatkan oleh perusahaan.

Waktu delay yang tinggi didapatkan karena adanya permasalahan dalam proses pergantian suhu yang drastis, material yang harus dilunakkan, kondisi mesin maupun faktor pada operator yang kurang tanggap dalam proses produksi.

Diagram Sebab - Akibat digunakan untuk meneliti lebih jauh terhadap permasalahan yang ada pada sistem produksi yang mengakibatkan rendahnya nilai Availability yang didapatkan dari penilaian OEE.

1. Material

Bahan baku yang digunakan oleh perusahaan merupakan Slab dimana bahan baku tersebut bersifat keras. Sehingga, apabila ada spesifikasi order tertentu maka bahan baku tersebut harus dilunakkan. 
2. Mesin / Peralatan

Kondisi mesin yang ada pada perusahaan juga mempengaruhi produksi, mesin tersebut sudah mengalami penurunan mesin dimana efektivitas mesin dalam memproduksi sudah tidak pada saat mesin baru dikarenakan umur mesin tersebut sudah tua.

3. Metode

Sesuai dengan spesifikasi order maka pada proses pengolahan bahan baku menjadi produk akhir dibutuhkan proses pergantian suhu yang drastis sesuai dengan sifat Slab tersebut. Suhu yang digunakan untuk proses produksi tidaklah sama pada setiap pembuatan Coil. Sehingga perlu di setting sehingga proses pelunakkan Slab menjadi lebih mudah.

4. Lingkungan

Pada proses produksi dibutuhkan pengaturan suhu yang sangat tinggi pada mesin sehingga mengakibatkan suhu di lingkungan disekitar pabrik pun meningkat dan juga ketika mesin mulai beroperasi suara yang dihasilkan juga menyebabkan kebisingan.

5. Manusia / Operator

Human error yang disebabkan kelelahan merupakan salah satu faktor penyebab terjadinya keterlambatan dalam proses produksi, sehingga fokus operator mengerjakan pekerjaannya berkurang.

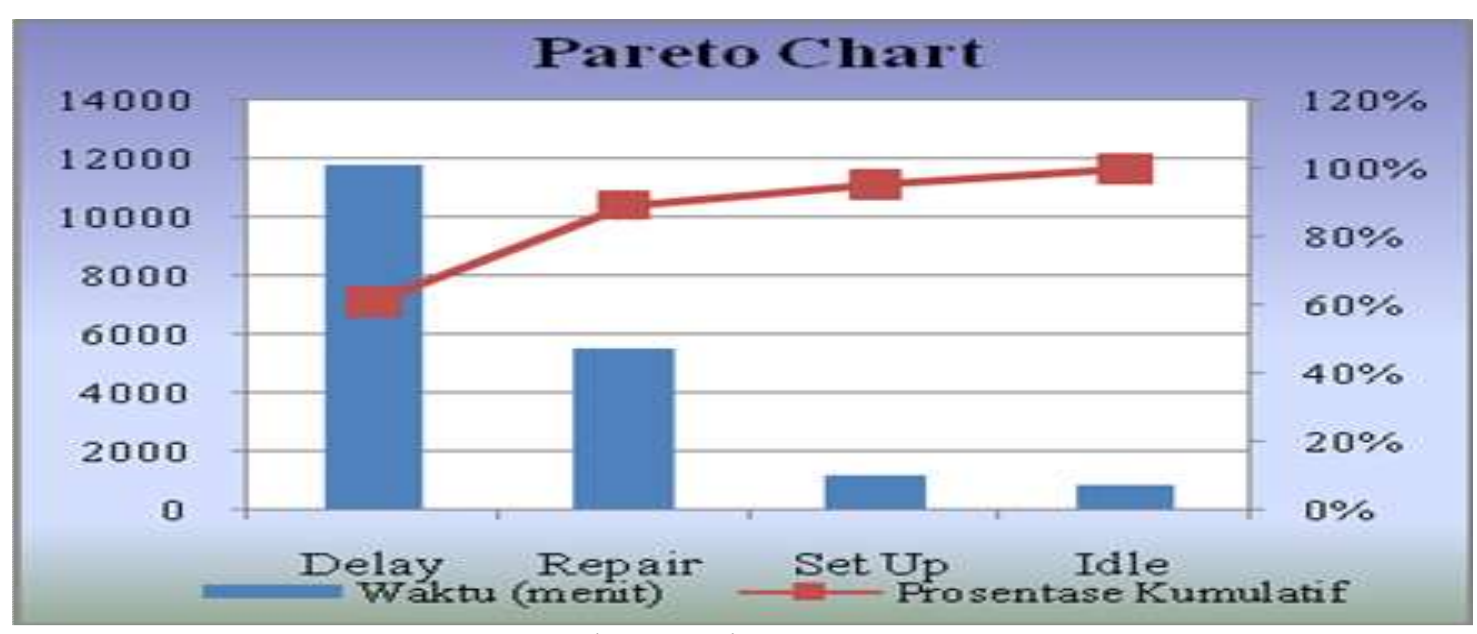

Gambar 2. Diagram Pareto.

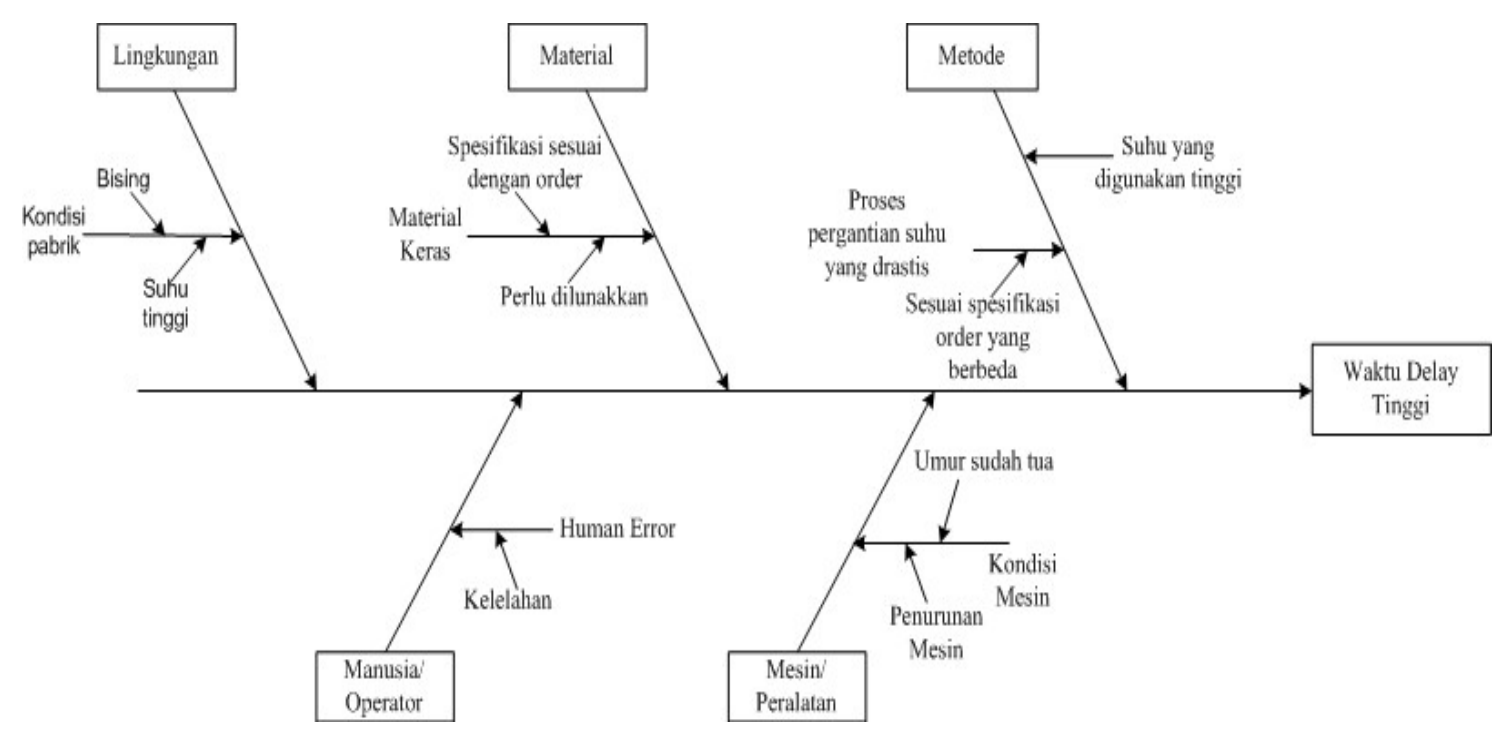

Gambar 3. Diagram Sebab - Akibat. 


\section{KESIMPULAN DAN SARAN 4.1. Kesimpulan}

Dari hasil penelitian yang telah dilakukan didapatkan kesimpulan sebagai berikut :

a. Berdasarkan pengukuran OEE, perusahaan memiliki skor yang rendah, dikarenakan tidak dapat memproduksi secara optimum. Perbandingan antara hasil pengukuran dan standar kelas dunia cukup jauh. Hasil aktual dari perusahaan adalah Availability sebesar $61 \%$, Performance sebesar 63\%, Quality sebesar 95\% dan OEE sebesar 42\%. Selisih antara hasil aktual dengan standar kelas dunia adalah Availability sebesar 29\%, Performance sebesar32\%, Quality sebesar 4,99\% dan OEE sebesar $43 \%$.

b. Rendahnya kinerja produksi pada periode Bulan Februari 2017 disebabkan karena faktor waktu reparature mesin dan waktu delay yang tinggi. Akan tetapi, tidak hanya dilihat dari segi data waktu produksi, produksi Hot Strip Mill dilakukan berdasarkan pesanan dari customer dengan demand yang berbedabeda dan tingkat kesulitan produksi. Perbedaan demand tersebut ada pada letak grade slab, deformation grup, length grup, thickness, width dan konsumen otomotif.

\subsection{Saran}

Berdasarkan hasil penelitian dan analisa yang telah dilakukan maka penulis memberikan saran :

a. Peningkatan kinerja produksi Hot Strip Mill dapat dilakukan dengan cara melakukan penjadwalan waktu reparasi sehingga kegiatan reparasi mesin tidak mengganggu mesin saat sedang memproduksi Hot StripMill. b. Perusahaan dapat menyusun jadwal produksi yang lebih ketat untuk mengoptimalkan kinerja mesin dan peralatan produksi. Penyusunan jadwal produksi disarankan untuk sesuai dengan spesifikasi order (grade) yang sama sehingga mengurangi penurunan mesin.

c. Dalam meningkatkan standar nilai OEE, perusahaan harus memperhatikan ketiga faktor dari penilaian OEE dimana nilai ketiganya yaitu Availability, Performance dan Quality harus seimbang. Keseimbangan tersebut didapatkan dari memaksimalkan waktu operasi dan meminimalkan waktu delay, idle mesin, dan juga menjadwalkan waktu reparasi.

\section{DAFTAR PUSTAKA}

A, V., Shetty, D. K., \& PrajualPJ., 2016. An Empirical Study Of Effect Of Total Productive Maintenance On Overall Equipment Effectiveness In A Water Bottling Industry. International Journal of Applied Engineering Research ISSN 09734562 Volume 11, No. 8, 5573-5579.

Esa, F., \& Yusof, Y., 2016. Implementing Overall Equipment Effectiveness (OEE) \& Suistainable Competititve Advantage: A Case Study Of Hicom Diecastings SDN. BHD. ARPN Journal of Engineering and Applied Sciences VOL. 11 NO. 1, 199-203.

Fahmi, A., Rahman, A., \& Efranto, R. Y., 2013. Implementasi Total Productive Maintenance sebagai Penunjang Produktivitas dengan Menggunakan Pengukuran Overall Equipment Effectiveness pada Mesin Rotary KTH-8 (Studi Kasus PT. Indonesian Tobacco). Jurnal Rekayasa \& Manajemen Sistem Industri Vol 1 No 1, Halaman 7584. 
Inc., V. I., 2016. World Class OEE. Dipetik Maret 13, 2017, dari Overall Equipment Effectiveness (OEE): http://www.oee.com/world-classoee.html.

Kigsirisina, S., Pussawiroa, S., \& Noohawmb, O., 2016. Approach for Total Productive Maintenance Evaluation in Water Productivity: A Case Study at Mahasawat Water Treatment Plant. Procedia Engineering 154, 260-267.

Lkiya, M. L., \& Kushwaha, D. K., 2015. Optimizing \& Analyzing Overall Equipment Effectiveness Through TPM Approach: A Case Study In Cement Industry. Scientific Journal of Impact Factor Volume 2, Issue 5, 807-811.

Nakajima, S., 1988. Introduction to TPM: Total Productive Maintenance. Cambridge: Productivity Press.

Patel, M., Kapadia, R., \& Joshi, G., 2016. Improvement of Overall Equipment Effectiveness of CNC Lathe Machine. International Journal of Engineering Science and Computing Volume 6 Issue No. 11, 3491-3494. 